\title{
BIOKATALIZATORY I BIOPOLIMERY W ASPEKCIE ZRÓWNOWAŻONEJ CHEMII
}

\author{
BIOCATALYSTS AND BIOPOLYMERS \\ IN THE ASPECT OF SUSTAINABLE CHEMISTRY
}

\section{Teofil Jesionowski, Lukasz Klapiszewski, Jakub Zdarta}

Politechnika Poznańska, Wydział Technologii Chemicznej, Instytut Technologii i Inżynierii Chemicznej, ul. Berdychowo 4, 60-965 Poznań

e-mail:Teofil.Jesionowski@put.poznan.pl; Lukasz.Klapiszewski@put.poznan.pl; Jakub.Zdarta@put.poznan.pl

\author{
Abstract \\ Wprowadzenie \\ 1. Wybrane aspekty zielonej chemii \\ 2. Biokatalizatory jako wydajne narzędzia w zielonej chemii \\ 3. Materiały odnawialne w aspekcie zrównoważonej chemii \\ Uwagi końcowe \\ Podziękowania \\ Piśmiennictwo cytowane
}




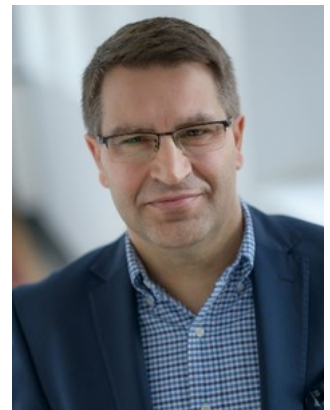

Prof. dr hab. inż. Teofil Jesionowski, czl. koresp. PAN jest pracownikiem Politechniki Poznańskiej nieprzerwanie od 1995 roku, przechodząc od tego czasu po dzień dzisiejszy wszystkie szczeble tzw. kariery naukowej. W 2013 roku uzyskał tytułu naukowy profesora nauk chemicznych, w dyscyplinie technologia chemiczna, a od roku 2020 pełni funkcję członka korespondenta PAN. Obecnie prof. Jesionowski jest rektorem Politechniki Poznańskiej (kadencja 2020-2024), przewodniczącym Konferencji Rektorów Polskich Uczelni Technicznych (KRPUT) (kadencja 2020-2024), członkiem Prezydium KRASP (aktualnie), członkiem Komisji ds. Współpracy Międzynarodowej KRASP (kadencje 2016-2020 i 2020-2024), członkiem Komisji ds. Akredytacji i Rankingów KRASP (kadencja 2020-2024) oraz członkiem Komisji ds. Strategicznych Problemów Szkolnictwa Wyższego KRASP (kadencja 20202024).

Autor ponad 440 publikacji naukowych, w tym niemal 390 artykułów indeksowanych przez Thomson Reuters $J C R, 30$ patentów (w tym 2 międzynarodowych) oraz 8 wdrożonych technologii. Ponadto, współautor 21 rozdziałów w monografiach, w tym 15 anglojęzycznych. Kierownik 11 oraz główny wykonawca 8 projektów oraz grantów badawczych, rozwojowych, celowych oraz europejskich, przyznawanych przez różne agendy, w tym KBN, NCN, NCBiR oraz MNiSW. Promotor w 20 przewodach doktorskich, 5 jego byłych doktorantów/magistrantów uzyskało najwyższy stopień naukowy. Ekspert NCN, NCBiR oraz F.R.S.-FNRS Belgia; NWO Holandia i DFG Niemcy.

Główne obszary badawcze prof. Jesionowskiego i jego zespołu stanowią: projektowanie, charakterystyka i zastosowania zaawansowanych materiałów funkcjonalnych, w tym układów hybrydowych; synteza inspirowana biomineralizacją i ekstremalna biomimetyka; biokompozyty i biomateriały; układy pigmentowe; funkcjonalne napełniacze i kompozyty polimerowe; immobilizacja enzymów; unieszkodliwianie uciążliwych dla środowiska zanieczyszczeń w wyniku zastosowania procesów adsorpcji, foto- i biokatalizy; chemia koloidów i modyfikacja powierzchni; biosensory i nanomedycyna.

https://orcid.org/0000-0002-7808-8060

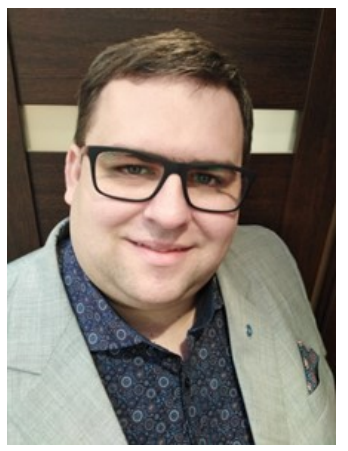

Dr hab. inż. Lukasz Klapiszewski, prof. PP, absolwent Wydziału Technologii Chemicznej Politechniki Poznańskiej (2010). W roku 2014 uzyskał stopień naukowy doktora nauk chemicznych w zakresie technologii chemicznej, a w 2019 stopień doktora habilitowanego w dziedzinie nauk ścisłych i przyrodniczych, dyscyplina nauki chemiczne. Od 2020 roku jest profesorem Politechniki Poznańskiej. Laureat licznych wyróżnień, w tym m.in. Stypendium Naukowego Miasta Poznania (2014), Nagrody Miasta Poznania za wyróżniającą się pracę doktorską (2016), Stypendium Ministra Nauki i Szkolnictwa Wyższego dla wybitnych młodych naukowców (2018), Nagrody Prezesa Rady Ministrów (2020), Nagrody Polskiego Towarzystwo Chemiczne za wyróżniające osiągnięcia naukowe (2020) i wielu innych.

Autor ponad 80 publikacji naukowych indeksowanych przez Thomson Reuters $J C R, 8$ rozdziałów w monografiach oraz 7 patentów. Kierownik lub wykonawca wielu projektów naukowo-badawczych finansowanych przez NCN, NCBiR oraz MNiSW. Ekspert Narodowego Centrum Nauki.

Zainteresowania naukowe: biopolimery, ze szczególnym uwzględnieniem ligniny; projektowanie, charakterystyka i zastosowanie funkcjonalnych materiałów/biomateriałów/ materiałów hybrydowych; kompozyty polimerowe; kompozyty cementowe; biokompozyty. 


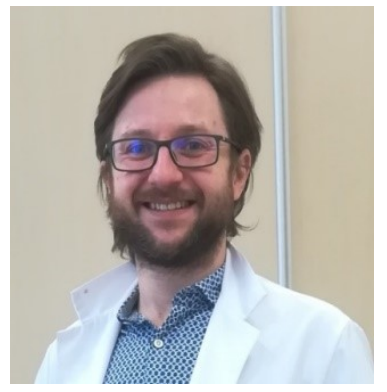

Dr hab. inż. Jakub Zdarta, absolwent Wydziału Chemii Uniwersytetu im. A. Mickiewicza w Poznaniu (tytuł zawodowy magistra uzyskany w 2010 r.) oraz Wydziału Technologii Chemicznej Politechniki Poznańskiej (tytuł zawodowy inżyniera otrzymany w 2013 r.). W roku 2017 uzyskał stopień naukowy doktora nauk chemicznych w zakresie technologii chemicznej. W latach 2017-2018 odbył staż naukowy typu postdoc w Center for BioProcess Engineering na DTU Chemical Engineering, Technical University of Denmark, a w 2019 r. odbył staż w School of Civil and Environmental Engineering, University of Technology Sydney. Laureat Stypendium Ministra Nauki i Szkolnictwa Wyższego dla wybitnych młodych naukowców (2019).

Autor ponad 60 publikacji naukowych indeksowanych przez Thomson Reuters JCR oraz 7 rozdziałów w monografiach. Kierownik lub wykonawca wielu projektów naukowobadawczych finansowanych przez NCN, NAWA oraz MNiSW.

Obszar badań naukowych koncentruje się na immobilizacji enzymów z różnych grup katalitycznych przy użyciu różnego rodzaju nośników pod kątem ich praktycznego zastosowania.

https://orcid.org/0000-0003-0268-2116 


\begin{abstract}
The rapid development of industry, apart from the obvious benefits, also leads to a significant increase in the level of environmental pollution, which is related not only to the use of harmful substances in the production process, but also to the production of significant amounts of by-products and wastes, which pose a serious threat to the environment as well as to the health and the life of living organisms. There is therefore a need to limit the use of toxic substances at every stage of production, and where this is not possible, appropriate waste management and the development of effective methods of harmful substances removal. In this respect, it seems crucial to introduce the principles of Green Chemistry as widely as possible. Green Chemistry is a concept whose main assumptions focus on designing and conducting chemical processes in a way that minimizes the use and formation of harmful substances as much as possible. This staretgy is based on twelve principles that overlap with the main assumptions of environmental chemistry to improve environmental protection and reduce pollution.

There are many techniques and methods that fit into the assumptions of the broadly understood Green Chemistry, the implementation of which allows for sustainable management of post-production waste and by-products as well as their effective disposal. One of such concepts assumes the use of waste substances as a valuable raw material, not only for energy, but above all as a precursor and/or component for the production of innovative materials with high utility potential. Another idea is the use of enzymes, i.e. natural biocatalysts that allow chemical transformations to be carried out under mild process conditions, without the need to use harmful solvents. What's more, enzymes can be used not only at the stage of conversion/synthesis of substrates, but they can also be efficient tools for removing harmful substances. Hence, it seems necessary to undertake attempts aimed at the widest possible management of waste substances, as well as conduct research, the effect of which is the production of functional biocatalytic systems for various applications.
\end{abstract}

Keywords: green chemistry, environmental protection, biocatalysis, biopolymers Słowa kluczowe: zielona chemia, ochrona środowiska, biokataliza, biopolimery 


\section{WPROWADZENIE}

Intensywny rozwój przemysłu, poza oczywistymi korzyściami, prowadzi także do znacznego wzrostu poziomu zanieczyszczenia środowiska, co związane jest nie tylko ze wykorzystaniem szkodliwych substancji w procesie produkcyjnym, ale także z wytwarzaniem znacznych ilości produktów ubocznych oraz odpadowych, które stanowią poważne zagrożenie dla środowiska oraz dla zdrowia i życia organizmów żywych. Istnieje zatem potrzeba wyeliminowania szkodliwych czy nawet toksycznych substancji na każdym etapie produkcji, a w przypadku gdy nie jest to możliwe, konieczne jest prowadzenie odpowiedniej gospodarki odpadami, a także opracowanie skutecznych metod usuwania szkodliwych substancji. Pod tym względem, kluczowe wydaje się jak najszersze wprowadzenie zasad Zielonej Chemii, a więc koncepcji, której główne założenia skupiają się na projektowaniu i prowadzeniu procesów chemicznych w sposób możliwie jak najbardziej ograniczający stosowanie i powstawanie szkodliwych substancji. Koncepcja ta oparta jest na dwunastu zasadach, które zazębiają się z głównymi założeniami chemii środowiskowej, a których celem jest poprawa jakości środowiska i ograniczenie jego zanieczyszczenia.

Istnieje wiele technik i metod wpisujących się w założenia szeroko rozumianej Zielonej Chemii, których wdrożenie pozwala na prowadzenie zrównoważonej gospodarki odpadami poprodukcyjnymi oraz ich efektywne usuwanie. Jedna z koncepcji zakłada wykorzystanie substancji odpadowych jako cennego surowca, nie tylko energetycznego, ale przede wszystkim jako prekursora i/lub komponentu do wytwarzania zaawansowanych materiałów o dużym potencjale użytkowym. Innym $\mathrm{z}$ pomysłów jest wykorzystanie enzymów, a więc naturalnych biokatalizatorów, które umożliwiają prowadzenie przemian chemicznych w łagodnych warunkach procesowych, bez konieczności stosowania szkodliwych rozpuszczalników. Co więcej, enzymy mogą być wykorzystane nie tylko na etapie konwersji/syntezy substratów, ale mogą stanowić także wydajne narzędzia umożliwiające unieszkodliwianie szkodliwych substancji. Stąd konieczne wydaje się podejmowanie prób mających na celu możliwie jak najszersze zagospodarowanie substancji odpadowych, jak i prowadzenia badań, których efektem jest wytworzenie funkcjonalnych układów biokatalitycznych do różnorodnych zastosowań. 


\section{WYBRANE ASPEKTY ZIELONEJ CHEMII}

Koncepcja Zielonej Chemii i jej zasady są jednymi ze sposobów, które prowadzą do minimalizacji zagrożeń związanych z działalnością człowieka, które w negatywny sposób oddziałują na środowisko. W 1998 roku Anastas i Warner sformułowali główne aspekty Zielonej Chemii, które mają na celu ograniczenie przedostawania się szkodliwych czy toksycznych substancji do środowiska poprzez szereg działań, jak na przykład ograniczenie przeprowadzania niebezpiecznych syntez chemicznych, wykorzystanie nietoksycznych i degradowalnych związków jako zamienników dla toksycznych reagentów, stosowanie surowców odnawialnych, używanie biokatalizatorów czy opracowanie nowoczesnych reakcji z udziałem katalizatorów prowadzących do degradacji związków toksycznych do mniej szkodliwych lub nietoksycznych pochodnych [1]. Na Rys. 1 przedstawiono treść 12 aspektów Zielonej Chemii [1-4].

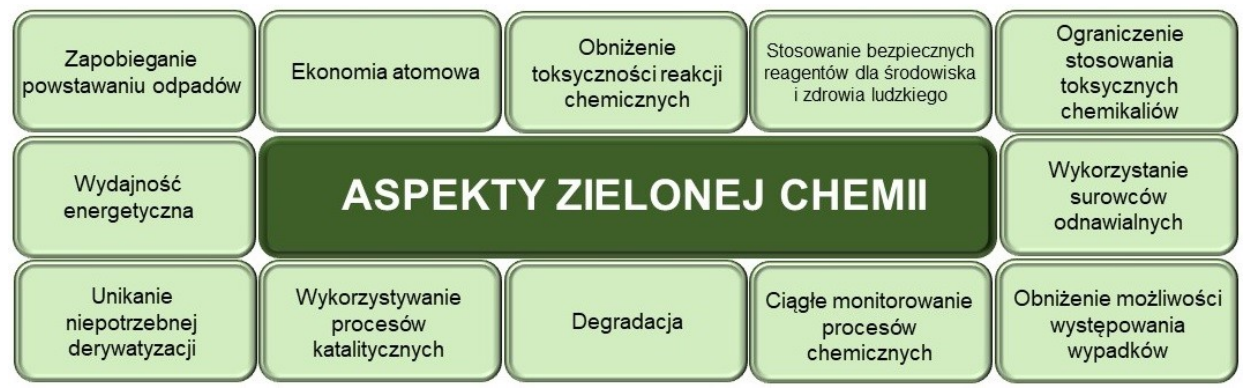

Rysunek 1. 12 głównych aspektów Zielonej Chemii Figure 1. 12 main aspects of Green Chemistry

Stosowanie się do zasad Zielonej Chemii w prowadzaniu procesów chemicznych stało się koniecznością z powodu stale postępującej degradacji środowiska i negatywnych zmian występujących na obszarze całych ekosystemów. Jednym z przykładowych procesów, które przebiegają zgodnie z zasadami Zielonej Chemii jest wytworzenie grafitu syntezowanego $\mathrm{z} \mathrm{CO}_{2}$. Liang i współpracownicy zwrócili w swojej pracy szczególną uwagę na przebieg reakcji syntezy grafitu, która odbywała się w niskich temperaturach, wynoszących poniżej $130^{\circ} \mathrm{C}$. Takie warunki termiczne procesu mogą być nawet nazywane ekstremalnie niskimi, jeśli porównać je ze standardowymi temperaturami wytwarzania grafitu, wynoszącymi nawet $1000^{\circ} \mathrm{C}$. Oprócz znacznego obniżenia nakładów energetycznych $\mathrm{w}$ procesie, zdecydowano się na zastosowanie jako reagentu wodorotlenku litowo-glinowego, zamiast standardowego katalizatora metalu przejściowego, co przełożyło się także na ograniczenie stosowania toksycznych chemikaliów w reakcji [5]. 
Jednym z obszarów, który w całości wpisuje się w zasady Zielonej Chemii, jest wykorzystywanie enzymów w szeregu reakcji biokatalitycznych, zarówno w skali laboratoryjnej, jak i przemysłowej. Na szczególną uwagę zasługują enzymy z grupy oksydoreduktaz, a w szczególności ich immobilizowane formy, które mogą stanowić efektywne narzędzia katalityczne w wielu syntezach chemicznych, jak $\mathrm{i}$ w usuwaniu zanieczyszczeń środowiskowych $\mathrm{z}$ roztworów wodnych, bez konieczności stosowania wysokich nakładów energetycznych oraz przy ograniczonym wykorzystaniu toksycznych rozpuszczalników [6]. Choć proces immobilizacji, a więc związania enzymu z nośnikiem wymaga pewnych nakładów finansowych, to warto również zwrócić uwagę na fakt, iż nośnikami w immobilizacji enzymów mogą być materiały pochodzenia naturalnego, które mogą stanowić odpad, występujący między innymi przy produkcji drewna czy przetwórstwie żywności [7, 8], co również wpisuje się w zasady Zielonej Chemii.

Oprócz wdrożenia zasad Zielonej Chemii w syntezach chemicznych czy degradacji zanieczyszczeń środowiskowych, warto zwrócić uwagę na różne gałęzie przemysłu, na przykład paliwowego czy papierniczego, wciąż zmieniające się zgodnie ze wszystkimi zasadami Zielonej Chemii. W ostatnich latach kładzie się coraz większy nacisk na wytwarzanie paliw z polimerów odnawialnych (np. gumy guar), a jest to spowodowane potrzebą ograniczania eksploatacji coraz to szybciej zmniejszających się zasobów ropy naftowej oraz jej negatywnego wpływu na środowisko i zdrowie ludzkie [9]. W przypadku przemysłu papierniczego, potrzeba zrównoważonej produkcji papieru i innych wyrobów papierniczych wynika ze stosowania ogromnych ilości zużywanych chemikaliów, energii i wody podczas modyfikacji drewna. Oprócz tego, w wyniku licznych reakcji chemicznych i modyfikacji termicznych, powstają duże ilości produktów odpadowych, w tym szkodliwych dla środowiska. Dlatego też proponowane są alternatywne i perspektywiczne metody przetwarzania drewna, które są przyjazne dla środowiska. Jednymi $\mathrm{z}$ nich są m.in zastosowanie enzymów w procesach delignifikacji, w miejsce standardowych, organicznych rozpuszczalników. Ważnymi związkami, które znajdują zastosowanie w przetwórstwie drewna, są także ciecze jonowe. Dzięki możliwości projektowania ich właściwości, mogą one być stosowane na każdym etapie przetwarzania drewna, eliminując wykorzystanie szkodliwych rozpuszczalników, a następnie produkcję toksycznych odpadów [10]. Mnogość i aktualność wszystkich aspektów Zielonej Chemii powoduje, że stają się one obecnie jednym z najważniejszych trendów, zgodnie z którymi projektuje się nowoczesne, zaawansowane, a przede wszystkim przyjazne dla środowiska procesy technologiczne. Co więcej nawet prace poznawcze realizowane w skali laboratoryjnej lub półtechnicznej, projektowane są obecnie nie tylko pod kątem ich 
wydajności, ale również $\mathrm{w}$ zgodzie $\mathrm{z}$ zaprezentowanymi aspektami Zielonej Chemii.

\section{BIOKATALIZATORY JAKO WYDAJNE NARZĘDZIA W ZIELONEJ CHEMII}

Jednym z podstawowych założeń Zielonej Chemii jest ochrona środowiska, nie tylko poprzez ograniczenie stosowania szkodliwych substancji i rozpuszczalników, ale także poprzez usuwanie niebezpiecznych związków z wód czy ścieków. Odnotowany w ostatnich dziesięcioleciach gwałtowny rozwój przemysłowy, urbanizacja i wykładniczy wzrost liczby ludności nie pozostały bez wpływy na środowisko, a woda jest jednym z głównych zasobów dotkniętych negatywnymi skutkami tych procesów. Wszystkie rodzaje zanieczyszczeń obecne zarówno w ściekach, jak i wodzie pitnej mają zasadniczy wpływ, bezpośrednio lub pośrednio, na zdrowie ludzi i prawidłowe funkcjonowanie organizmów wodnych. Dotąd potwierdzono obecność w wodach i ściekach m.in.: związków fenolowych, barwników, pestycydów, farmaceutyków, a nawet hormonów, co wynika z ciągle rosnącego wykorzystania tych substancji. Co więcej, związki te stosowane są nie tylko w różnego rodzaju branżach przemysłowych, ale są także powszechnie wykorzystywane w rolnictwie, medycynie, a także w gospodarstwach domowych. Wspomniane substancje, przedostają się do ścieków lub wód gruntowych w niekontrolowanych ilościach i stanowią globalny problem, gdyż długotrwały i niekontrolowany kontakt lub ich spożycie może prowadzić do poważnych zaburzeń metabolicznych, genetycznych, a także wywoływać choroby wielu układów wewnętrznych w organizmach żywych.

Przedstawione powyżej fakty powodują, iż usuwanie nawet śladowych ilości substancji fenolowych $\mathrm{i}$ ich pochodnych $\mathrm{z}$ roztworów wodnych staje się koniecznością. Jednym z rozwiązań opartych na zasadach Zielonej Chemii jest zastosowanie specjalistycznych metod, które umożliwiają wydajną remediację określonej grupy substancji (Rys. 2). Pod tym kątem niezwykle atrakcyjne wydaje się wykorzystanie mikroorganizmów, a także pozyskanych z nich enzymów, jako narzędzi o wysokiej selektywności, które są w stanie rozkładać/konwertować nawet związki odporne na biologiczną degradację, w tym substancje niebezpieczne dla środowiska i zdrowia organizmów żywych. Do metod tych zalicza się wykorzystanie immobilizowanych enzymów, a w szczególności lakaz, peroksydaz i tyrozynaz czy biomolekuł należących do grupy oksydoreduktaz [11,12]. Takie systemy charakteryzują się nie tylko wysoką stabilnością w różnych warunkach reakcyjnych, ale również stanowią efektywne narzędzia w usuwaniu zanieczyszczeń fenolowych, z roztworów wodnych. 


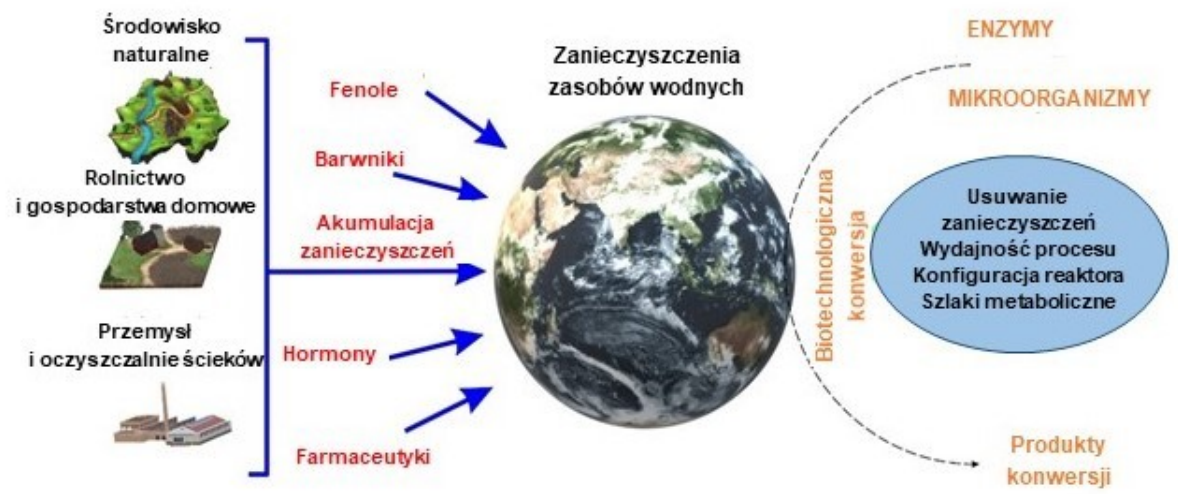

Rysunek 2. Idea wykorzystania metod biotechnologicznych do usuwania zanieczyszczeń środowiskowych, w oparciu o [11]

Figure 2. The concept of using biotechnological methods to remove environmental pollution, based on [11]

Immobilizowane enzymy znajdują coraz szersze wykorzystanie w procesach remediacji szkodliwych substancji i umożliwiają usunięcie wspomnianych związków z wysokimi wydajnościami. Systemami biokatalitycznymi, na które warto zwrócić szczególną uwagę pod względem zastosowania w usuwaniu barwników z roztworów wodnych, są nośniki tlenkowe z unieruchomioną lakazą. Układy tlenkowe $\mathrm{TiO}_{2}-\mathrm{ZrO}_{2}$ oraz $\mathrm{TiO}_{2}-\mathrm{ZrO}_{2}-\mathrm{SiO}_{2}$ zostały wykorzystane $\mathrm{w}$ adsorpcyjnej immobilizacji lakazy, a następnie wytworzone biokatalizatory heterogeniczne posłużyły jako narzędzia w usuwaniu barwników: Alizarin Red (C.I. Mordant Red 3), Remazol Brilliant Blue R (C.I. Reactive Blue 19) oraz C.I. Reactive Black $5 \mathrm{z}$ roztworów wodnych. Zaobserwowano synergiczną dekoloryzację otrzymanych roztworów barwników na drodze adsorpcji molekuł barwników na układach tlenkowych oraz biokonwersji za pomocą unieruchomionej lakazy [13]. W innej pracy wykorzystano układ $\mathrm{ZrO}_{2}-\mathrm{SiO}_{2}$ oraz $\mathrm{ZrO}_{2}-\mathrm{SiO}_{2}$ modyfikowany jonami miedzi jako nośnik $\mathrm{w}$ procesie immobilizacji lakazy, a następnie $\mathrm{w}$ usuwaniu barwnika tekstylnego C.I. Reactive Blue 19 z roztworów wodnych. Wytworzone systemy biokatalityczne pozwoliły nie tylko uzyskać ponad 90-proc. dekoloryzację roztworu barwnika, ale również obniżyć toksyczność roztworu po degradacji o $40 \%$, w porównaniu do roztworu barwnika przed reakcją [14].

Kolejnymi układami, które mogą posłużyć w efektywnym usuwaniu barwników $\mathrm{z}$ roztworów wodnych są systemy złożone $\mathrm{z}$ materiałów elektroprzędzonych oraz immobilizowanych oksydoreduktaz. Włókna wytworzone metodą elektroprzędzenia, dzięki swoim właściwościom, jakimi są wysoka porowatość czy obecność wielu grup funkcyjnych na ich powierzchni, mogą stano- 
wić efektywne nośniki w procesie unieruchomienia enzymów. Przykładem materiału elektroprzędzonego, zastosowanego w procesie immobilizacji lakazy metodą adsorpcji oraz wiązania kowalencyjnego, a następnie degradacji ww. barwnika, jest układ wytworzony z poli(metakrylanu metylu) i polianiliny (PMMA/PANI). Po 24 godz. reakcji za pomocą systemu z zaadsorbowaną oraz unieruchomioną kowalencyjnie lakazą, efektywność dekoloryzacji barwnika Remazol Brilliant Blue R (C.I. Reactive Blue 19) wynosiła odpowiednio 87\% i 58\% [15]. Innym materiałem elektroprzędzonym, który znalazł zastosowanie jako nośnik w immobilizacji enzymów oraz w usuwaniu barwników z roztworów wodnych jest nylon 6 . Na włóknach $\mathrm{z}$ nylonu 6 zostały unieruchomione takie enzymy jak lakaza i peroksydaza chrzanowa metodą adsorpcyjną i wiązania kowalencyjnego. Zaobserwowano, iż zastosowanie takich układów pozwala nie tylko na efektywne usuwanie barwników: C.I. Reactive Black 5, C.I. Basic Green 4 i C.I. Reactive Blue 4, ale również możliwa jest dekoloryzacja tych związków z modelowych roztworów wody morskiej. Pozwala to stwierdzić, iż systemy z unieruchomionymi oksydoreduktazami mogą być stosowane w usuwaniu barwników z rzeczywistych roztworów wodnych [16,17].

Jednak poza wykorzystaniem do usuwania barwników, oksydoreduktazy immobilizowane na materiałach elektroprzędzonych doskonale sprawdzają się także w procesach usuwania innych zanieczyszczeń środowiskowych, takich jak: bisfenole, czy substancje farmaceutycznie aktywne. Doskonały przykład stanowi materiał elektroprzędzony polikaprolakton-chitozan, który został wykorzystany do adsorpcyjnej immobilizacji tyrozynazy, a powstały system biokatalityczny zastosowano w procesach usuwania bisfenolu A. Interesującym zabiegiem, którego celem było wytworzenia systemów o jak najwyższej aktywności, było wykorzystanie wieloczynnikowej regresji wielomianowej (z ang. multivariate polynomial regression). Pozwoliło to na wykazanie, że optymalnymi parametrami procesu immobilizacji było: $\mathrm{pH} 7$, temperatura $25^{\circ} \mathrm{C}$ i 16 godzin trwania procesu. W tych warunkach powstał nowy typ systemu biokatalitycznego o wydajności immobilizacji 93\% i aktywności 95\%. Ponadto tak przygotowany układ zastosowano do biodegradacji bisfenolu A (BPA) w różnych warunkach procesowych. Na podstawie tych danych można stwierdzić, że ponad $80 \%$ BPA zostało usunięte po $120 \mathrm{~min}$ procesu, w zakresie temperatur $15-45^{\circ} \mathrm{C}$ oraz w zakresie pH 6-9 z roztworu bisfenolu A o stężeniu $3 \mathrm{mg} / \mathrm{L}$ [18]. Alternatywnym rozwiązaniem dla stosowania immobilizowanej tyrozynazy do usuwania bisfenoli jest wykorzystanie lakazy $\mathrm{z}$ Trametes versicolor unieruchomionej na trójwymiarowym szkielecie gąbki morskiej z gatunku Hippospongia communis. Powstałe systemy biokatalityczne wykorzystano do biodegradacji trzech bisfenoli: bisfenolu A (BPA), bisfenolu F (BPF) oraz odpornego na biologiczną degradację 
bisfenolu S (BPS). Przeprowadzono optymalizację metodologii immobilizacji i biodegradacji w celu zwiększenia efektywności usuwania bisfenoli i oceniono wpływ temperatury, $\mathrm{pH}$ oraz początkowego stężenia zanieczyszczeń na wydajność remediacji. Wykazano, że w optymalnych warunkach prawie $100 \%$ BPA (pH 5, $\left.30^{\circ} \mathrm{C}\right)$ i BPF $\left(\mathrm{pH} 5,40^{\circ} \mathrm{C}\right)$, oraz ponad $40 \%$ BPS $\left(\mathrm{pH} 4,30^{\circ} \mathrm{C}\right)$ zostało usunięte z roztwór o stężeniu $2 \mathrm{mg} / \mathrm{mL}$. Ponadto unieruchomiona lakaza wykazywała znaczną możliwość wielokrotnego użycia i stabilność podczas przechowywania, zachowując ponad $80 \%$ swojej początkowej aktywności po 50 dniach przechowywania oraz umożliwiając usunięcie ponad $40 \%$ bisfenoli nawet po 5 cyklach katalitycznych. Zidentyfikowano także główne produkty biodegradacji BPA i BPF i wykazano, że w wyniku utleniania bisfenoli przez unieruchomioną lakazę powstawały głównie dimery i trimery, które charakteryzują się znacznie niższą szkodliwością niż pierwotne związki [19].

Obiecujące rezultaty osiągnięte $\mathrm{z}$ wykorzystaniem naturalnych sponginowych szkieletów gąbki morskiej spowodowały, że podjęto także próbę wykorzystania chitynowych szkieletów gąbek morskich Aplysina archeri do immobilizacji lakazy, a powstałe układy biokatalityczne chityna - enzym zastosowano do usuwania tetracykliny, jako jednego $\mathrm{z}$ najpowszechniej spotykanych antybiotyków. Potwierdzeniem wysokiej aktywności unieruchomionego enzymu była możliwość całkowitego usunięcia tetracykliny z roztworów w stężeniach do $1 \mathrm{mg} / \mathrm{L}$ zaledwie po $60 \mathrm{~min}$ prowadzenia procesu. Co więcej, dzięki ochronnemu działaniu chitynowych szkieletów i stabilizacji enzymu poprzez wielopunktowe przyłączenie, stabilność biokatalizatorów podczas przechowywania oraz w podwyższonej temperaturze uległa znacznej poprawie, w porównaniu z wolnym enzymem. Z kolei znaczny potencjał aplikacyjny otrzymanych układów potwierdzono poprzez ich wykorzystanie w reaktorze ze złożem stałym, co umożliwiło osiągnięcie ponad 80proc. wydajności usuwania antybiotyku nawet po 24 godzinach ciągłego stosowania [20].

Szeroki wachlarz potencjalnych nośników do immobilizacji enzymów o znacznym potencjale środowiskowym został także uzupełniony o mezoporowate materiały krzemionkowe. Ze względu na wyjątkowe właściwości teksturalne, morfologiczne oraz mechaniczne, mezostrukturalna pianka komórkowa ( $\mathrm{z}$ ang. mesostructured cellular foam, MCF) okazał się odpowiednim materiał do immobilizacji m.in. lakazy. Celem poprawy właściwości katalitycznych enzymu przed procesem jego immobilizacji, materiał poddano modyfikacji jonami miedzi, uzyskując ponad 90-proc. wydajność procesu immobilizacji. Po unieruchomieniu, lakaza zachowywała wysoką aktywność katalityczną (ponad $80 \%$ w szerokim zakresie temperatur $\left(20-40^{\circ} \mathrm{C}\right)$ i $\mathrm{pH}(4-7)$ w porównaniu $\mathrm{z}$ wolnym enzymem, który wykazywał tak wysoką aktywność tylko w pH 5 i $30^{\circ} \mathrm{C}$. 
Wartym podkreślenia jest, że modyfikacja nośnika krzemionkowego pozwoliła na hiperkatywację unieruchomionego enzymu, co w konsekwencji przełożyło się na całkowite usunięcie tetracykliny z roztworów wodnych na drodze jednoczesnej adsorpcji oraz enzymatycznej konwersji, jednak ze zdecydowaną przewagą biokatalitycznego usuwania farmaceutyku [21].

Uniwersalność oraz możliwość projektowania właściwości materiałów elektroprzędzonych pod kątem danego enzymu oraz procesu w którym ma zostać wykorzystany znajduje swoje zastosowanie także w procesie enzymatycznego usuwania substancji farmaceutycznie aktywnych, takich jak antybiotyki, czy niesteroidowe leki przeciwzapalne. Hybrydowy materiał elektroprzędzony z poli(metakrylan metylu) wzbogacony nanocząstkami magnetycznymi został wykorzystany jako nośnik do kowalencyjnego związania, jak i enkapsulacji lakazy z Trametes versicolor. Wysokie powinowactwo enzymu do nośnika oraz stabilność wytworzonych wiązań znajduje swoje odzwierciedlenie w niewielkiej ilości wymytego w trakcie procesu enzymu. Ponadto otrzymane układy biokatalityczne charakteryzowały się wysoką stabilnością w zmiennych warunkach $\mathrm{pH}$ i temperatury oraz zachowały ponad $80 \%$ swoich początkowych właściwości po 40 dniach przechowywania i 5 kolejnych cyklach biokatalitycznych. Wykazano także, że obie formy unieruchomionej lakazy mają wysoką zdolność do przekształcania tetracykliny, bowiem w optymalnych warunkach procesu $\left(\mathrm{pH} 5\right.$, temperatura $25^{\circ} \mathrm{C}$, stężenie roztworu tetracykliny $1 \mathrm{mg} / \mathrm{L}$ ) skuteczność usuwania osiągnęła $100 \%$ i 94\% dla kowalencyjnie związanej i kapsułkowanej lakazy. Zbadano także produkty degradacji, aby określić jej mechanizm. Dowiedziono, że utlenianie, odwodornienie i demetylacja są głównymi reakcjami, jakim podlega tetracykliny w trakcie enzymatycznej konwersji, co prowadzi do powstania produktów mniej szkodliwych niż wyjściowa substancja [22]. Interesującym rozwiązaniem w enzymatycznej biodegradacja farmaceutyków, przy użyciu enzymów, jest także wykorzystanie systemów opartych o hybrydowe materiały elektroprzędzone poli(kwas-l-mlekowy)-ko-poli(e-kaprolakton) połączonych z lakazą (Rys. 3). Wytworzone układy biokatalityczne zastosowano do biodegradacji dwóch powszechnie stosowanych leków przeciwzapalnych, naproksenu i diklofenaku, które występują w ściekach w stężeniach istotnych dla środowiska. Analizując otrzymane wyniki wykazano, że w optymalnych warunkach procesowych (temperatura $25^{\circ} \mathrm{C}, \mathrm{pH} 5$ i 3 odpowiednio dla naproksenu i diklofenaku), nawet z roztworu o stężeniu $1 \mathrm{mg} / \mathrm{L}$ możliwe jest usunięcie ponad $90 \%$ obu farmaceutyków. Co więcej, zastosowanie wspomnianych nanowłókien elektroprzędzonych powoduje, że unieruchomione enzymy wykazały wysoką przydatność do ponownego użycia, bowiem po pięciu cyklach katalitycznych około $60 \%$ i $40 \%$ naproksenu i diklofenaku zostało usunięte. O pozytywnym wpływie 
stosowanych systemów na środowisko dobitnie świadczy również fakt, że badanie toksyczności mieszaniny po biodegradacji farmaceutyków pozwoliło wykazać, że roztwory otrzymane po procesie były o ponad 65\% mniej toksyczne niż początkowe roztwory naproksenu i diklofenaku [23].

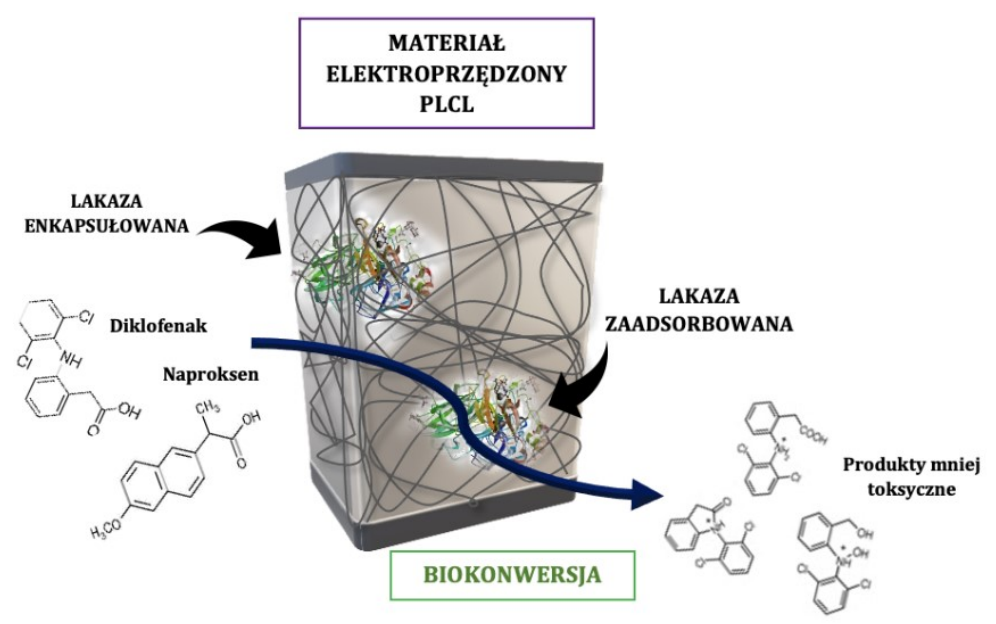

Rysunek 3. Wykorzystanie lakazy unieruchomionej poprzez adsorpcję oraz enkapsulację z wykorzystaniem materiału elektroprzędzonego poli(kwas-l-mlekowy)-ko-poli(\&-kaprolakton) do biodegradacji diklofenaku oraz naproksenu. Przedruk z literatury [23] za zgodą Elsevier

Figure 3. Application of laccase immobilized by adsorption and encapsulation using electrospun material poly(L-lactic acid)-co-poly(e-caprolactone) for the biodegradation of diclofenac and naproxen. Reproduced from [23] with permission from Elsevier

Zaprezentowane dane jednoznacznie wskazują, że wykorzystanie immobilizowanych enzymów w procesach usuwania wybranych zanieczyszczeń środowiskowych wpisuje się w założenia Zielonej Chemii prowadząc do znacznej eliminacji niebezpiecznych substancji. Jednak założenia Zielonej Chemii motywują także do poszukiwań bardziej przyjaznych dla środowiska dróg konwersji substratów do wartościowych produktów. Dodatkowo, jak wspomniano już wcześniej, niezwykle istotne jest możliwie jak najszersze wykorzystanie dostępnych surowców, w tym w szczególności surowców pochodzenia naturalnego. $\mathrm{W}$ ten nurt doskonale wpisują się prace związane $\mathrm{z}$ wykorzystaniem immobilizowanych enzymów w procesach konwersji składników biomasy.

Wszystkie wspomniane powyżej aspekty zostały poruszone w pracy, w której jako nośnik do immobilizacji celulazy z Aspergillus niger wykorzystano materiał hybrydowy tlenek tytanu-lignina, powstały $\mathrm{z}$ myślą $\mathrm{o}$ zagospodarowaniu odpadowego produktu, jakim jest lignina, przy jednoczesnym zapewnieniu odpowiedniej ilości reaktywnych grup funkcyjnych niezbędnych do efektywnego 
związana enzymu. Biokatalizator został skutecznie osadzony na nieorganicznoorganicznej matrycy hybrydowej, głównie poprzez fizyczne interakcje, a optymalizacja procesu immobilizacji pozwoliła na wskazanie, że pH 5, czas trwania procesu 6 godzin i początkowe stężenie roztworu enzymu $5 \mathrm{mg} / \mathrm{mL}$ pozwalają na otrzymanie preparatów enzymatycznych o wysokiej aktywności. Ponadto dowiedziono, że termiczna i chemiczna stabilność celulazy uległa zwiększeniu, w porównaniu z wolnym enzymem, bowiem po 3 godzinach inkubacji w temperaturze $50^{\circ} \mathrm{C}$ i pH 6 , immobilizowana celulaza zachowała ponad $80 \%$ swojej początkowej aktywności. Ponadto czas półtrwania immobilizowanej celulazy (307 min) był pięciokrotnie większy niż wolnego enzymu (63 min). Powstałe $\mathrm{w}$ ten sposób układy biokatalityczne, poza możliwością zagospodarowania produktów odpadowych, w doskonały sposób wpisują się w założenia Zielonej Chemii, bowiem mogą znaleźć praktyczne zastosowanie w zrównoważonej i przyjaznej dla środowiska hydrolizie celulozy.

Jednak procesy hydrolizy celulozy, to nie jedyne procesy konwersji biomasy, które w ostatnich latach nabierają szczególnego znaczenia. Ze względu na wyczerpujące się zasoby naturalne, poszukuje się ich alternatyw, a źródłem wielu, niezwykle cennych substancji okazała się biomasa. Pozyskane głównie z celulozy i hemicelulozy związki, jak np. monosacharydy mogą być konwertowane do związków o wysokiej wartości użytkowej, które znajdują zastosowanie w przemyśle spożywczym, chemicznym czy farmaceutycznym. Stąd pomysł wykorzystania w enzymatycznej konwersji ksylozy oraz glukozy, odpowiednio do kwasu ksylonowego oraz kwasu glukonowego, dehydrogenazy ksylozowej (XDH) oraz dehydrogenazy glukozowej (GDH) immobilizowanych na materiałach krzemionkowych o zróżnicowanej morfologii. W omawianych badaniach wykorzystano mezoporowatą krzemionką SBA-15 oraz nanocząstki krzemionki, w celu zdefiniowania wpływu rodzaju nośnika na właściwości i stabilność enzymu, a otrzymane układy testowano w bioreaktorze enzymatycznym (Rys. 4). Po immobilizacji oba enzymy wykazały znaczną poprawę ich stabilności termicznej i odporności w zasadowym $\mathrm{pH}$ oraz wykazywały ponad 50-proc. aktywność nawet w $\mathrm{pH} 10$ i $60^{\circ} \mathrm{C}$. W porównaniu $\mathrm{z}$ wolnymi enzymami, w $45^{\circ} \mathrm{C}, \mathrm{GDH}$ unieruchomiony na nanocząstkach krzemionki i mezoporowatej krzemionce wykazał odpowiednio 4,5 i 7,25-krotny wzrost czasu półtrwania, podczas gdy XDH unieruchomiony na nanoSiO${ }_{2}$ i SBA-15 wykazał 4,7 i 9,5-krotną poprawę czasu półtrwania. Dodatkowo po pięciu cyklach reakcyjnych, zarówno nanoSiO ${ }_{2} \mathrm{GDH}$, jak i nanoSiO 2 XDH zachowały ponad $40 \%$ aktywności, a GDH i XDH unieruchomione na krzemionce SBA wykazały zachowanie około 50\% swojej początkowej aktywności, co skutkowało około 1,5-1,6-krotnym wzrostem produktywności biokatalitycznej, w porównaniu z wolnymi enzymami. Uzyskane 
dane jasno wskazuję na znaczny potencjał aplikacyjny tych układów, zwłaszcza uwzględniając fakt, że procesy enzymatycznej konwersji prowadzono z roztworów rzeczywistych [24].

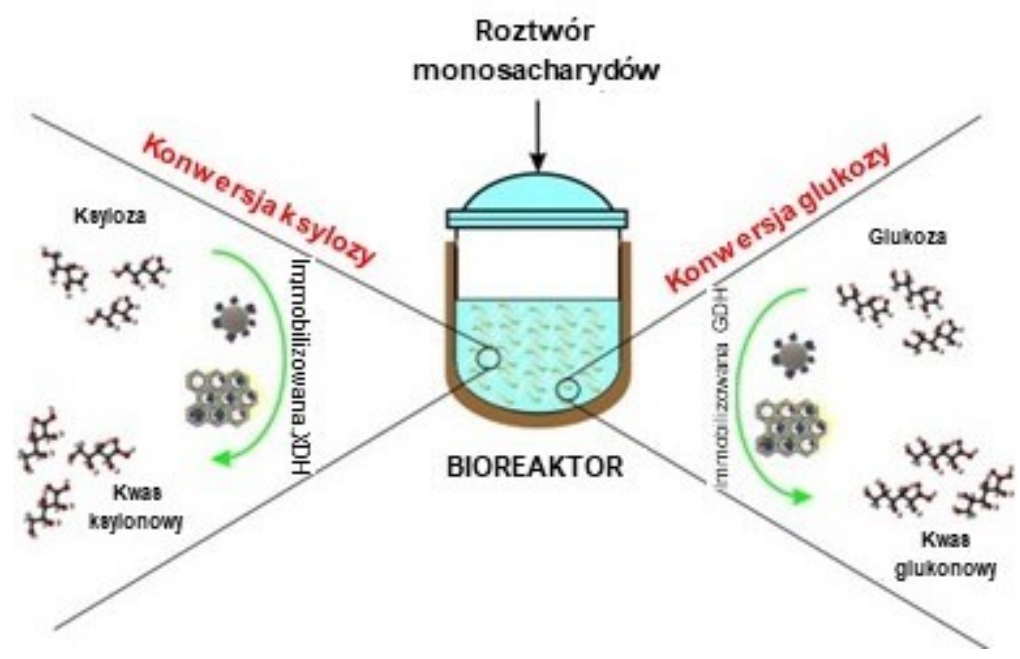

Rysunek 4. Schematyczne zaprezentowanie idei enzymatycznej konwersji monosacharydów katalizowanej przez dehydrogenazę ksylozową $(\mathrm{XDH})$ oraz dehydrogenazę glukozową (GDH) immobilizowane na materiałach krzemionkowych. Przedruk z literatury [24] za zgodą Elsevier

Figure 4. Schematic presentation of the idea of enzymatic conversion of monosaccharides catalyzed by xylose dehydrogenase $(\mathrm{XDH})$ and glucose dehydrogenase $(\mathrm{GDH})$ immobilized on silica materials. Reproduced from [24] with permission from Elsevier

Konwersja składników biomasy katalizowana przez immobilizowane enzymy jest obiecującym sposobem otrzymywania wartościowych związków o wysokiej wydajności w łagodnych warunkach. Jednak jednoczesna przemiana glukozy i ksylozy w kwas glukonowy i kwas ksylonowy jest pomijanym obszarem badań. Wyzwanie to stanowiło inspirację dla następnej pracy, w której podjęto badania nad koimmobilizacją GDH i XDH przy użyciu mezoporowatej krzemionki SBA-15, dla jednoczesnej produkcji kwasu glukonowego i ksylonowego. Potwierdzono skuteczną koimmobilizację enzymów na powierzchni i w porach podłoża krzemionkowego. Dowiedziono także, że dla konwersji ksylozy i glukozy najbardziej odpowiedni był stosunek GDH:XDH równy 1:5, ponieważ wydajność reakcji osiągnęła ponad $90 \%$ dla obu monosacharydów po 45 minutach procesu. Po koimmobilizacji stwierdzono wydajności reakcji przekraczające $80 \% \mathrm{w}$ szerokich zakresach $\mathrm{pH}(7-9)$ i temperatury $\left(40-60^{\circ} \mathrm{C}\right)$. Ponadto koimmobilizowane GDH i XDH wykazały znaczną poprawę stabilności termicznej, chemicznej i podczas przechowywania. Co więcej, wytworzone układy biokatalityczne charakteryzują się znaczną przydatnością do ponownego użycia, gdyż wykazały wydajność reakcji na poziomie powyżej $80 \%$, nawet po 5 kolejnych cyklach reakcji [25]. 
Zebrane dane jasno wskazują na znaczny potencjał immobilizowanych biokatalizatorów w procesach prowadzonych zgodnie $\mathrm{z}$ założeniami Zielonej Chemii. Przedstawione informacje dowodzą także, że wspomniane układy mogą być także postrzegane jako narzędzia Zielonej Chemii i służyć dbałości oraz poprawie stanu środowiska. Jednakże, pomimo niewątpliwych osiągnieć poczynionych $\mathrm{w}$ tym zakresie, ciągle potrzebne są dalszej prace, które pozwolą pokonać istniejące ograniczenia i umożliwią na transfer opracowanych rozwiązań do zastosowań przemysłowych.

\section{MATERIALY ODNAWIALNE W ASPEKCIE ZRÓWNOWAŻONEJ CHEMII}

Zielonej Chemii należy traktować jako jedną ze strategii działań zmierzających do zmniejszenia zagrożeń środowiska naturalnego. Tym samym wpisuje się ona w ramy rozwoju zrównoważonego. Wdrażanie zasad zielonej chemii przyczynia się do skutecznej ochrony środowiska naturalnego głównie poprzez wykorzystanie surowców odnawialnych (zasada 7) [1, 2]. Zasada ta zaleca stosowanie wszędzie tam, gdzie tylko to możliwe surowców odnawialnych. Wykorzystanie takich surowców pozwala zaoszczędzić surowce kopalne, których zasoby z każdym rokiem zmniejszają się i ogranicza niekorzystne dla środowiska konsekwencje ich przerobu. Najważniejszą pozycję wśród surowców odnawialnych zajmuje biomasa, na którą składają się: ligninoceluloza, skrobia, oleje roślinne, białka roślinne i izoprenoidy [3, 4]. Biomasę wykorzystuje się jako komponenty do syntez związków chemicznych oraz do produkcji biopaliw, które uważa się za najbardziej przyjazne dla środowiska, tym samym stanowią one o rozwoju zrównoważonej chemii $[1,2]$.

W dzisiejszych czasach bardzo ważną rolę odgrywa właściwe zagospodarowanie biomasy pochodzenia roślinnego zbudowanej $\mathrm{z}$ odpowiednich pojedynczych komórek. Komórki te charakteryzują się wielowarstwową strukturą, w której centrum znajduje się cytoplazma z zawieszonymi organellami. Całość otoczona jest błoną cytoplazmatyczną, którą z kolei ogranicza ściana komórkowa. Rdzeń komórki roślinnej okrywa warstwa wtórna ściany komórkowej (z ang. secondary wall), składająca się z trzech warstw, którą to otacza warstwa pierwotna (z ang. primary wall) [26, 27].

Warstwa wtórna ściany komórkowej rośliny zbudowana jest z odpowiednio zorientowanej celulozy, hemicelulozy i ligniny (Rys. 5). Najbardziej zewnętrzną częścią komórki roślinnej jest blaszka środkowa, której zadaniem jest separacja sąsiadujących komórek roślinnych. Ta zewnętrzna warstwa zbudowana jest głównie z ligniny i polisacharydów [26-29]. 


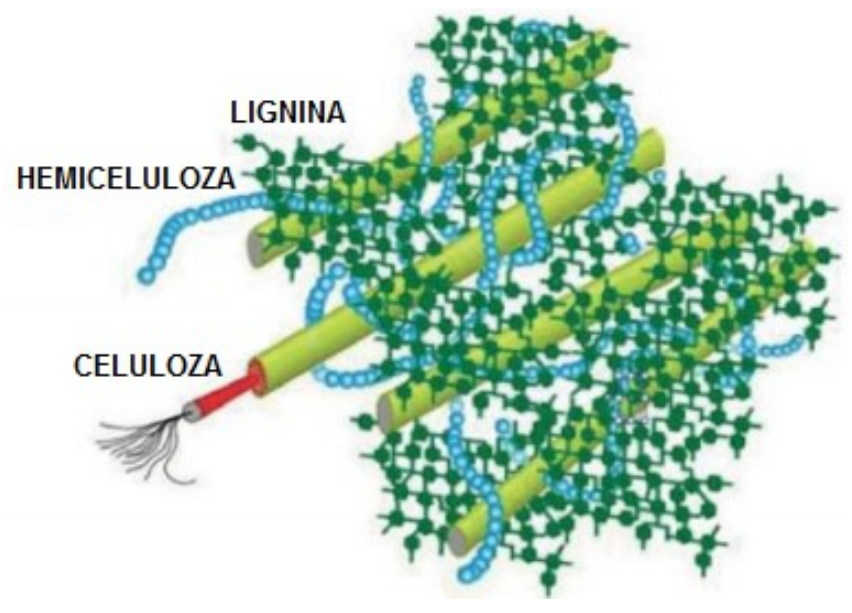

Rysunek 5. Struktura biomasy roślinnej, w oparciu o [28]

Figure 5. The structure of plant biomass, based on [28]

Powszechnie występująca w naturze pojedyncza komórka roślinna ma średnicę od 10 do $50 \mu \mathrm{m}$ oraz długość od 1 do $50 \mathrm{~mm}$. Komórki są zorientowane względem siebie równolegle, tworząc bardziej zorganizowaną strukturę, czyli mikrofibryle. Natomiast wyższym stopniem organizacji charakteryzują się włókna, które tworzą równolegle upakowane makrofibryle. Cząsteczki celulozy występujące w warstwie wtórnej, tworzą krystaliczne, łańcuchowe, spiralnie skręcone struktury, dzięki czemu zapewniają wysoką wytrzymałość mechaniczną włókien rośliny. Występująca w komórce roślinnej hemiceluloza, łączy się z celulozą wiązaniami wodorowymi, tworząc tym samym sieć celulozowo-hemicelulozową. Natomiast lignina pełni funkcję inkrustującą układ celulozy i hemicelulozy, nadając sztywność roślinie. Hemiceluloza oraz lignina, występujące w warstwie wtórnej komórki roślinnej, tworzą wyłącznie obszary amorficzne [29].

Najpowszechniej występującym w przyrodzie polisacharydem, a ponadto jednym z najistotniejszych naturalnych materiałów, któremu do chwili obecnej poświęcono wiele prac naukowych jest celuloza. Wchodzi ona nie tylko w skład masy lignocelulozowej, ale może być również syntezowana przez algi, osłonice i niektóre bakterie. Celuloza jest polimerem składającym się z jednostek Danhydroglukopiranozowych połączonych ze sobą wiązaniami $\beta$-1,4glikozydowymi. Obecnie uważa się, że podstawową jednostką powtarzalną w cząsteczce celulozy jest nie celobioza, a glukoza. Wzór ogólny celulozy zapisywany jest jako $\left(\mathrm{C}_{6} \mathrm{H}_{10} \mathrm{O}_{5}\right)_{\mathrm{n}=10000-15000}$, gdzie liczba reszt glukozy $n$ zależy od źródła pochodzenia celulozy [30]. Obecność w strukturze celulozy dużej liczby wiązań wewnątrz- i międzycząsteczkowych umożliwia jej różnorodne ułożenie przestrzenne. Przywołane wiązania tworzone są przez wolne grupy hydroksylowe 
i atomy tlenu obecne zarówno w pierścieniach piranozowych, jak i wiązaniach glikozydowych makrocząsteczek biopolimeru. Znane są cztery podstawowe odmiany polimorficzne celulozy - celuloza I, II, III oraz IV. Różnią się one między sobą rozmiarami komórek elementarnych oraz przynależnością do grupy krystalograficznej [30,31].

Dzięki dużej zawartości grup hydroksylowych, celuloza z łatwością ulega modyfikacji z otrzymaniem np. estrów czy eterów, które mogą mieć potencjalne znaczenie jako nowe nośniki substancji aktywnych w lekach lub mogą występować w roli regulatorów tempa uwalniania substancji aktywnej do organizmu [32]. Dostępne są również doniesienia literaturowe dotyczące homogenicznej reakcji estryfikacji celulozy z wykorzystaniem cieczy jonowych. Dzięki ich udziałowi w reakcji możliwe jest otrzymywanie znanych pochodnych biopolimeru, ale również proponowanie nowych typów syntez [33].

Celuloza znajduje szerokie zastosowanie $\mathrm{w}$ produkcji papieru, tektury oraz wiskozy [27]. Ze względu na wysoką chłonność wody, krystaliczna nanoceluloza znajduje zastosowanie w maseczkach oraz kremach nawilżających [26]. Opracowano również nowe materiały opatrunkowe na bazie nanocelulozy, które mogą z powodzeniem zostać zastosowane w leczeniu oparzeń i owrzodzeń [26, 27]. Nanoceluloza została również wykorzystana do otrzymania mikrorurek (BASYC ${ }^{\circledR}$ $\mathrm{z}$ ang. BActerial SYnthesised Cellulose), które można zastosować jako zamienniki naczyń krwionośnych. Włókna nanocelulozy z powodzeniem mogą zostać również zastosowane w połączeniu z powszechnie stosowanymi polimerami, jako przyjazne środowisku biokompozyty, co jest istotnie rozwijanym tematem przez liczne zespoły badawcze w kraju [34-37], jak i zagraniczne [38-41]. Materiały celulozowo-polimerowe charakteryzują się interesującymi zaletami, tj.: relatywnie niewielką ceną oraz niską gęstością. Należy jednak także zwrócić uwagę na takie ograniczenia, jak: niski moduł rozciągający, wysoka adsorpcja wody oraz ograniczona rozpuszczalność [26]. Warto w tym miejscu przytoczyć także metodę syntezy kompozytu celuloza - grafen (CGC) zaproponowaną przez Zhang i innych, co pozwoliło opracować interesujące zastosowanie kompozytu w ochronie środowiska, jako funkcjonalnego adsorbentu szkodliwych pestycydów opartych na triazynie. Wysoka stabilność otrzymanego materiału umożliwia na jego wielokrotne wykorzystanie w procesie adsorpcji [42]. W innych badaniach, naukowcy otrzymali gąbczasty biokompozyt chitozan - celuloza z użyciem chlorku 1-allilo-3metyloimidazoliowego [AMIM]Cl. Finalnie zaprojektowany materiał o wyglądzie gąbki, charakteryzował się aktywnością przeciwbakteryjną przeciwko $S$. aureus oraz E. coli. Wykorzystana w procesie ciecz jonowa w łatwy sposób ulega regeneracji, tym samym ponownie mogła zostać użyta $w$ procesie syntezy kompozytu, przyczyniając się do wzrostu znaczenia Zielonej Chemii [43]. Inną 
alternatywę, wykorzystując celulozę do otrzymania nanokompozytowych filmów nanorurki węglowe - celuloza zaproponował Huang i współpracownicy, których nowo zaprojektowane układy były przyjazne dla środowiska, a dodatkowo charakteryzowały się bardzo dobrymi właściwościami mechanicznymi oraz stosunkowo wysokim przewodnictwem elektrycznym [44].

Znaczenie biomateriałów opartych na celulozie jest bardzo duże. W ostatnim czasie powstała znaczna ilość prac naukowych podejmujących temat tego biopolimeru, co przyczyniło się do odnalezienia nowych, potencjalnych ścieżek wykorzystania omawianego związku.

Z kolei, hemicelulozy to wspólna nazwa wszystkich wielocukrów występujących (oprócz celulozy i pektyn) w ścianach komórkowych roślin wyższych, spełniających funkcję substancji matrycowych i sklejających. Niektóre $\mathrm{z}$ nich należą do substancji zapasowych [45]. Omawiany biopolimer ma strukturę rozgałęzioną, w której wyróżnić można inne jednostki węglowodanowe, niż 1,4- $\beta$ glukopiranozy. Dodatkową cechą, odróżniającą ją od celulozy, jest od 10 do 100krotnie niższy stopień polimeryzacji. Ponadto składniki, z których zbudowana jest hemiceluloza, ściśle odpowiadają konkretnemu gatunkowi rośliny [26]. Do grupy hemiceluloz należą m.in.: ksylany, mannany, galaktany oraz galaktomannany.

Ksylany są bardzo ważnym składnikiem hemiceluloz, ponieważ wraz z ligniną i celulozą wchodzą w skład kompleksu ligninocelulozowego w ścianach komórkowych roślin. Należą do heteropolisacharydów roślinnych. Łańcuchy ksylanów są kompleksem jednostek D-ksylanopiranozowych połączonych wiązaniem $\beta-1,4$ lub $\beta-1,3$ [45].

Mannany to polisacharydy zbudowane $\mathrm{z}$ reszt mannopiranozy, $\mathrm{D}$ glukopiranozy i D-galaktopiranozy, połączonych wiązaniami $\beta$-1,4-glikozydowymi. Tak zbudowany typ heteropolimerów nazywa się glukomannanami (czyli polisacharydami, w których stosunek reszt galaktozy do glukozy i mannozy wynosi 0,1:1:4). Z kolei, stosunek reszt mannozy do reszt glukozy wynosi 3:1. Mannany otrzymują nazwę w zależności od tego, z jakich reszt są zbudowane [45].

Natomiast galaktany zawierają $\mathrm{w}$ swojej budowie łańcuchy boczne reszt $\mathrm{D}$ galaktozy, połączonych $\mathrm{z}$ łańcuchem głównym wiązaniami $\beta$-1,4. Kwasy $\mathrm{D}$ glukuronowy i D-galakturonowy tworzą w nich rozgałęzienia głównego łańcucha, łącząc się z nim wiązaniami $\beta$-1,6-glikozydowym. W końcu, galaktomannany występują przede wszystkim w nasionach roślin strączkowych, w których stanowią polisacharydy zapasowe. Łańcuch główny stanowią reszty mannozy połączone ze sobą wiązaniami $\beta$-1,4-glikozydowymi, do którego wiązaniami $\alpha-1,6$ dołączone są reszty D-galaktopiranozy [45]. 
Hemiceluloza znajduje zastosowanie w wielu gałęziach przemysłu, m.in.: w farmacji, jako nośnik substancji aktywnej leków, a także w przemyśle spożywczym, jako składniki modyfikujące smak jedzenia. Omawiany biopolimer charakteryzuje się niską wartością kaloryczną, a ponadto stymuluje rozwój „dobrych” kultur bakterii w przewodzie pokarmowym, dzięki czemu jest naturalnym prebiotykiem. Potencjalnie hemiceluloza może zostać zastosowana jako dodatek do mieszanek polimerowych, co umożliwia otrzymanie bioaktywnych i biokompatybilnych kompozytów [46]. Z naukowego punktu widzenia hemiceluloza stanowi ciekawą alternatywę do celulozy, co daje duże szanse, że tematyka dotycząca tego biopolimeru zostanie $w$ najbliższych latach zintensyfikowana.

Obok celulozy i hemicelulozy, lignina jest trzecim podstawowym składnikiem biomasy drzewnej. Udział procentowy ligniny w roślinie jest zróżnicowany, co zależy przede wszystkim od jej rodzaju - średnio kształtuje się jednak na poziomie $20 \%$ [47]. Pierwsze wzmianki o ligninie sięgają początku XIX wieku, kiedy to szwajcarski botanik Augustin Pyramus de Candolle wprowadził pojęcie la lignine (z języka francuskiego) i tym mianem określił nierozpuszczalną frakcję drewna [48]. Od tego momentu po dzień dzisiejszy trwa intensywny rozwój wiedzy dotyczącej ligniny, który w ostatnich latach uległ gwałtownej intensyfikacji, o czym świadczą dane zaczerpnięte z bazy Scopus (na dzień 21.05.2021 r. dane dla frazy lignin kształtowały się następująco, do roku: 2000 - 15164 odsłon; 2010 - 29552 i 2021 - 73056 [49].

$\mathrm{Na}$ budowę strukturalną ligniny składają się trzy podstawowe monomery (alkohole $p$-kumarylowy, koniferylowy oraz sinapinowy) [50, 51]. Udział poszczególnych alkoholi $\mathrm{w}$ roślinie uwarunkowany jest rodzajem materiału roślinnego (drewno miękkie, drewno twarde, trawy jednoliścienne etc.), jego pochodzeniem oraz odpowiednią strefą klimatyczną, w której występuje. Ważną kwestią, na którą warto także zwrócić uwagę jest tworzenie różnych typów wiązań kowalencyjnych pomiędzy monomerami, do których w przypadku ligniny należą wiązania eterowe oraz wiązania typu węgiel - węgiel [48, 51]. Najpowszechniej występującym wiązaniem dla wszystkich modeli strukturalnych ligniny (od 35 do $70 \%$ wszystkich wiązań, w zależności od rodzaju drewna) jest wiązanie eterowe $\beta$ O-4 powstające pomiędzy węglem $\beta$ a czwartym atomem węgla [51].

Głównym producentem ligniny i/lub jej pochodnych, wytwarzającym kilkadziesiąt milionów ton produktu rocznie jest przemysł celulozowo-papierniczy, który wykorzystuje powstały biopolimer najczęściej w celach energetycznych (około 95-98\%) [48, 52]. Ten aspekt zastosowania związany jest z niską wartością dodaną ligniny. Oprócz możliwości pozyskiwania energii, ligninę oraz jej pochodne można wykorzystać $\mathrm{w}$ innych konwencjonalnych zastosowaniach, m.in. jako: 
napełniacze polimerów, domieszki do kompozytów cementowych, substytuty w produkcji żywic fenolowo-formaldehydowych czy innych [48, 52-55]. Ponadto porowate mikrosfery $\mathrm{z}$ udziałem ligniny są wykorzystywane jako efektywne sorbenty, głównie ze względu na ich wysoką porowatość i obecność licznych powierzchniowych grup funkcyjnych [56-58]. Schematycznie zostało to zaprezentowane na Rys. 6.

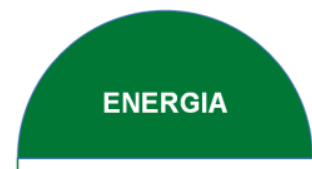

Spalanie ligniny lub jej pochodnych dla celów energetycznych

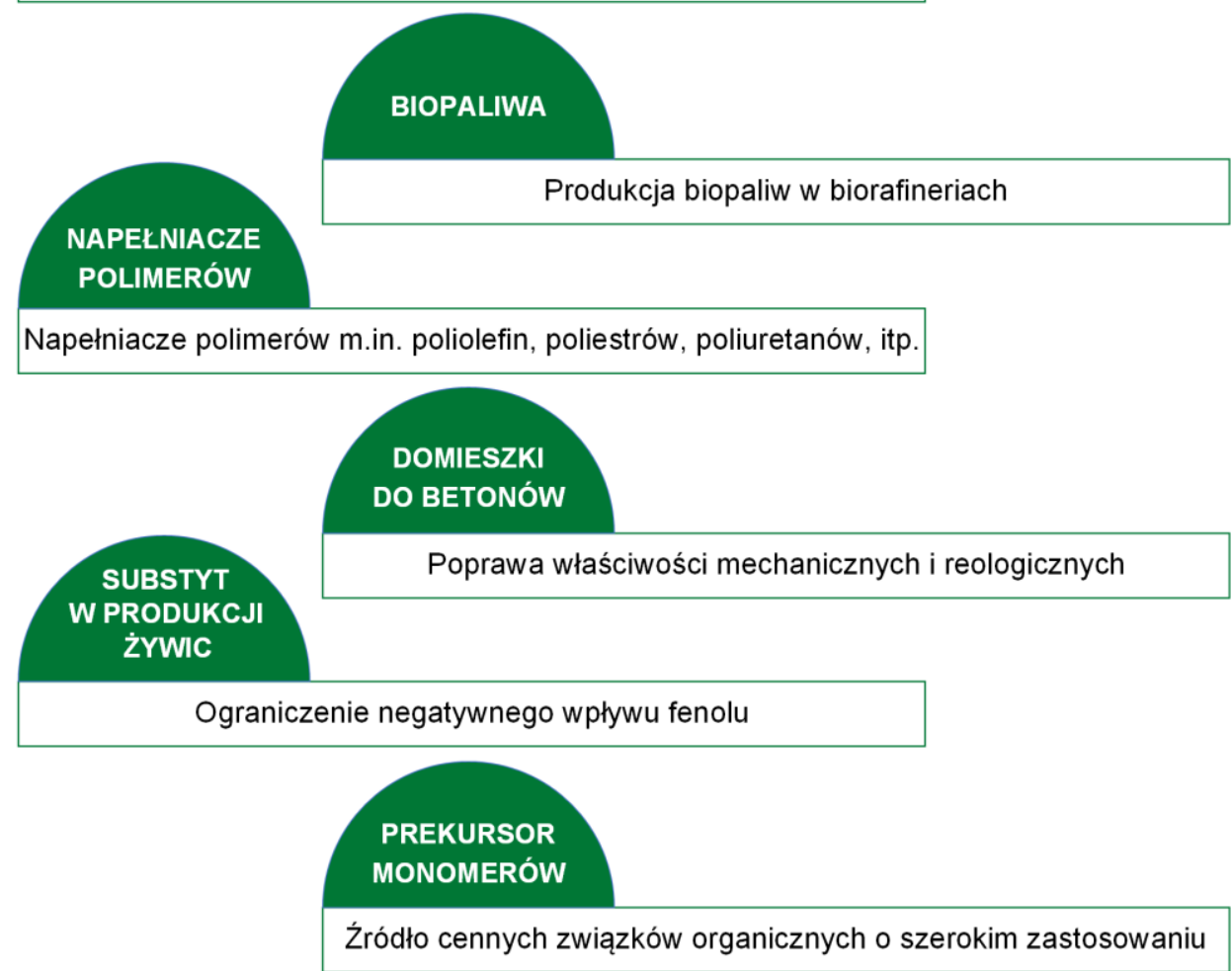

Rysunek 6. Przemysłowe zastosowanie ligniny, na podstawie [48, 52-55]

Figure 6. Industrial use of lignin, based on [48, 52-55]

$\mathrm{W}$ ostatnich latach badania związane $\mathrm{z}$ ligniną i/lub jej pochodnymi uległy zintensyfikowaniu. Jest to spowodowane głównie różnorodnością grup funkcyjnych obecnych w strukturze ligniny, które w relatywnie łatwy sposób można poddać modyfikacjom, nadając tym samym produktowi nowych/ulepszonych właściwości. Stąd, obecnie, główne kierunki zastosowania ligniny można podzielić na dwie zasa- 
dnicze grupy: (i) nie uwzględniając wcześniejszej modyfikacji chemicznej biopolimeru, poprzez co związek wykorzystany jako komponent lub wbudowany w matrycę nadaje nowych/ulepszonych właściwości produktom docelowym; (ii) uwzględniając uprzednią modyfikację chemiczną biopolimeru, co umożliwia otrzymać szeroką grupę "projektowalnych" produktów, a także nowej generacji funkcjonalne materiały/biomateriały/materiały hybrydowe oraz polimery o specjalnych właściwościach.

W ostatnim czasie, nastąpił wzrost zainteresowania projektowaniem, otrzymywaniem oraz zastosowaniem zaawansowanych, funkcjonalnych materiałów hybrydowych $\mathrm{z}$ udziałem ligniny $\mathrm{i} / \mathrm{lub}$ jej pochodnych. Wytworzone układy wykorzystuje się m.in. jako: nośniki enzymów [59-61], efektywne sorbenty jonów metal szkodliwych dla środowiska [62-65], produkty o właściwościach magnetycznych [66], napełniacze polimerów [67-75], dodatki do materiałów ściernych [76-79] czy domieszki do kompozytów cementowych [80-82]. Wybrane materiały hybrydowe $\mathrm{z}$ udziałem ligniny wraz $\mathrm{z}$ potencjalnym zastosowaniem zestawiono na Rys. 7.

Prowadzone badania, związane $\mathrm{z}$ tematyką ligniny, spowodowały w konsekwencji rozwój dodatkowej ścieżki badawczej - próby wykorzystania przyjaznych dla środowiska cieczy jonowych w roli "zielonych", „projektowalnych" związków umożliwiających modyfikację struktury biopolimeru [83-86]. W tym celu wykorzystano powszechnie znane, relatywnie tanie i przyjazne dla środowiska ciecze jonowe, ale także zaprojektowano grupę nowych ILs, które wykorzystane $\mathrm{w}$ warunkach lagodnego utleniania w powietrzu odpowiednio modyfikowały strukturę ligniny zwiększając zawartość ugrupowań karbonylowych. Ma to istotne znaczenie pod kątem wykorzystania produktów w różnych dziedzinach nauki, w tym elektrochemii, gdzie zasadność wykorzystania m.in. układów hybrydowych $\mathrm{SiO}_{2}$-lignina potwierdzono we wcześniej opublikowanych pracach [87-89].

Ważnym nurtem badawczym jest także próba zaprojektowania funkcjonalnych mikro- i nanostruktur o sferycznym kształcie, głównie z udziałem ligniny kraft. Układy takie znajdują potencjalne zastosowanie jako selektywne systemy do dostarczania leków, w immobilizacji enzymów oraz w ochronie środowiska [90, 91]. 


\section{$\mathrm{SiO}_{2}$-lignina}

napełniacz polimerów, biosorbent, materiał elektrodowy, dodatek do mieszanek betonowych, dodatek do materiałów ściernych

\section{ZnO-lignina}

materiał antybakteryjny, napełniacz polimerów,

materiał fotoaktywny

\section{$\mathrm{GO}_{\mathbf{x}}-\mathrm{SiO}_{2}$-lignina}

biosensor do określania zawartości glukozy

\section{$\mathrm{Al}_{2} \mathrm{O}_{3}$ - i cBN-lignina}

dodatek do materiałów ściernych

\section{Chityna-lignina} z rzeczywistych ścieków przemysłowych

\section{$\mathrm{TiO}_{2}$-lignina}

biosorbent, immobilizacja enzymów

\section{Montmorylonit-lignina}

adsorpcja barwników ze ścieków przemysłowych

Rysunek 7. Wybrane materiały hybrydowe $\mathrm{z}$ udziałem ligniny wraz $\mathrm{z}$ potencjalnym zastosowaniem, na podstawie [59-82]

Figure 7. Selected hybrid materials with the participation of lignin together with their potential application, based on [59-82]

Przewiduje się, że najbliższym czasie tematyka związana z projektowaniem funkcjonalnych materiałów/biomateriałów, w tym hybrydowych, z udziałem ligniny i/lub jej pochodnych ulegnie jeszcze większemu zintensyfikowaniu. Jest to związane ze stale postępującym wzrostem znaczenia biopolimerów, jako produktów odnawialnych oraz ograniczeniem wydobycia ropy naftowej. Powiązane jest to z kolei nieodłącznie $\mathrm{z}$ aspektem Zielonej Chemii i Gospodarką Obiegu Zamkniętego.

\section{UWAGI KOŃCOWE}

W ostatnim czasie uwidocznił się postępujący wzrost znaczenia substancji naturalnych, jako funkcjonalnych prekursorów i/lub komponentów do wytwarzania zaawansowanych materiałów o dużym potencjale użytkowym. Ważną rolę odgrywają tutaj: celuloza, hemiceluloza oraz, coraz powszechniej, lignina i jej pochodne. Wykorzystanie surowców odnawialnych skutecznie wpływa na ochronę środowiska 
naturalnego, przyczyniając się do wzrostu znaczenia Zielonej Chemii. Innym z pomysłów, mających na celu zrównoważoną gospodarkę produktami, jest wykorzystanie enzymów, stanowiących naturalne biokatalizatory. Umożliwiają one prowadzenie przemian chemicznych w łagodnych warunkach procesowych, bez konieczności stosowania szkodliwych rozpuszczalników. Związki te oprócz możliwości ich wykorzystania na etapie konwersji czy syntezy substratów, mogą stanowić również wydajne narzędzia umożliwiające usuwanie szkodliwych substancji.

Wyszczególnione dwa główne nurty badawcze, którym poświęcona została niniejsza publikacja stanowią bardzo rozwojowe obszary, które $\mathrm{z}$ pewnością w najbliższym czasie będą rozwijane i wdrażane do gospodarki.

\section{PODZIECKOWANIA}

Autorzy niniejszą prace dedykują Panu prof. Bogdanowi Burczykowi, wybitnemu specjaliście z zakresu chemii surfaktantów i układów zdyspergowanych oraz chemii acetali i eterów.

Praca naukowa została częściowo sfinansowana ze środków Ministerstwu Edukacji i Nauki w ramach przyznanej subwencji badawczej dla Politechniki Poznańskiej.

\section{PIŚMIENNICTWO CYTOWANE}

[1] Cz. Puchała, Chem. Environ. Biotechnol., 2013, 14, 7.

[2] B. Burczyk, Wiad. Chem., 2009, 63, 739.

[3] B. Burczyk, Biomasa. Surowiec do syntez chemicznych i produkcji paliw, Oficyna Wyd. Politechniki Wrocławskiej, Wrocław, 2011.

[4] Cz. Puchała, Technika, Informatyka, Inżynieria Bezpieczeństwa, 2014, 2, 277.

[5] C. Liang, Y. Chen, M. Wu, K. Wang, W. Zhang, Y. Gan, H. Huang, J. Chen, Y. Xia, J. Zhang, S. Zheng, H. Pan, Nat. Comm., 2021, 12, 19.

[6] B. Liu, B. Chen, B. Zhang, X. Song, G. Zeng, K. Lee, J. Hazard. Mater., 2021, 402, 123456.

[7] M. Bilal, H.M.N. Iqbal, Int. J. Biol. Macromol., 2019, 130, 462.

[8] K. Jankowska, F. Ciesielczyk, K. Bachosz, J. Zdarta, E. Kaczorek, T. Jesionowski, Materials, 2019, 12, 1252.

[9] A.M.A. Hasan, M.E. Abdel-Raouf, Egypt. J. Petroleum, 2018, 27, 1043.

[10] E.I. Akpan, B. Wetzel, K. Fredrich, Green Chem., 2021, 23, 2198.

[11] J. Zdarta, L.N. Nguyen, K. Jankowska, T. Jesionowski, L.D. Nghiem, Crit. Rev. Environ. Sci. Technol., DOI: 10.1080/10643389.2021.1889283.

[12] J. Zdarta, A.S. Meyer, T. Jesionowski, M. Pinelo, Biotechnol. Adv., 2019, 37, 107401.

[13] K. Antecka, J. Zdarta, K. Siwińska-Stefańska, G. Sztuk, E. Jankowska, P. Oleskowicz-Popiel, T. Jesionowski, Catalysts, 2018, 8, 402.

[14] K. Jankowska, F. Ciesielczyk, K. Bachosz, J. Zdarta, E. Kaczorek, T. Jesionowski, Materials, 2019, 12, 1252.

[15] K. Jankowska, J. Zdarta, A. Grzywaczyk, E. Kijeńska-Gawrońska, A. Biadasz, T. Jesionowski, Environment. Res., 2020, 184, 109332. 
[16] K. Jankowska, A. Grzywaczyk, A. Piasecki, E. Kijeńska-Gawrońska, L.N. Nguyen, J. Zdarta, L.D. Nghiem, M. Pinelo, T. Jesionowski, Environment. Technol. Innov., 2021, 21, 101332.

[17] K. Jankowska, J. Zdarta, A. Grzywaczyk, O. Degórska, E. Kijeńska-Gawrońska, M. Pinelo, T. Jesionowski, Process Biochem., 2021, 102, 10.

[18] J. Zdarta, M. Staszak, K. Jankowska, K. Kaźmierczak, O. Degórska, L.N. Nguyen, E. KijeńskaGawrońska, M. Pinelo, T. Jesionowski, Int. J. Biol. Macromol., 2020, 165, 2049.

[19] J. Zdarta, K. Antecka, R. Frankowski, A. Zgoła-Grześkowiak, H. Ehrlich, T. Jesionowski, Sci. Total Environ., 2018, 615, 784.

[20] J. Zdarta, T. Machałowski, O. Degórska, K. Bachosz, A. Fursov, H. Ehrlich, V.N. Ivanenko, T. Jesionowski, Biomolecules, 2020, 10, 646.

[21] J. Zdarta, A. Feliczak-Guzik, K. Siwińska-Ciesielczyk, I. Nowak, T. Jesionowski, Micropor. Mesopor. Mater., 2020, 291, 109688.

[22] J. Zdarta, K. Jankowska, K. Bachosz, E. Kijeńska-Gawrońska, A. Zgoła-Grześkowiak, E. Kaczorek, T. Jesionowski, Catal. Tod., 2020, 348, 127.

[23] J. Zdarta, K. Jankowska, M. Wyszowska, E. Kijeńska-Gawrońska, A. Zgoła-Grześkowiak, M. Pinelo, A.S. Meyer, D. Moszyński, T. Jesionowski, Mat. Sci. Eng. C, 2019, 103, 109789.

[24] J. Zdarta, M. Pinelo, T. Jesionowski, A.S. Meyer, ChemCatChem, 2018, 10, 5164.

[25] J. Zdarta, K. Bachosz, O. Degórska, A. Zdarta, E. Kaczorek, M. Pinelo, A.S. Meyer, T. Jesionowski, Materials, 2019, 12, 3167.

[26] S. Kalia, B.S. Kaith, I. Kaur, Cellulose fibers: Bio- and nano-polymer composites, Springer, Berlin, 2011.

[27] D. Klemm, B. Heublein, H.P. Fink, A. Bohn, Angew. Chem. Int. Ed., 2005, 44, 3358.

[28] S. Wang, Z. Luo, Pyrolysis of biomass, Volume 1, Walter de Gruyter GmbH, Berlin, 2017.

[29] Ł. Klapiszewski, T.J. Szalaty, T. Jesionowski, Lignina jako produkt odpadowy przemysłu celulozowo-papierniczego - zastosowanie oraz aspekt środowiskowy, w: Środowisko i przemysł. Tom VI, red. G. Schroeder, P. Grzesiak, Cursiva, Poznań, 2016.

[30] J.-L. Wertz, O. Bédué, J.P. Mercier, Cellulose Science and Technology, EPFL Press, Lausanne, 2010.

[31] D. Klemm, B. Philipp, T. Heinze, U. Heinze, W. Wagenknecht, Comprehensive Cellulose Chemistry: Fundamentals and Analytical Methods, Volume 1, Wiley-VCH Verlag GmbH, Weinheim, 1998.

[32] N. Kar, H. Liu, K.J. Edgar, Biomacromolecules, 2011, 12, 1106.

[33] J. Zhang, W. Chen, Y. Feng, J. Wu, J. Yu, J. He, J. Zhang, Polym. Int., 2015, 64, 963.

[34] D. Zielińska, T. Rydzkowski, V.K. Thakur, S. Borysiak, Ind. Crop. Prod., 2021, 161, 113188.

[35] D. Zielińska, K. Szentner, A. Waśkiewicz, S. Borysiak, Materials, 2021, 14, 2124.

[36] E. Szefer, A. Leszczyńska, E. Hebda, K. Pielichowski, J. Renew. Mater., 2021, 9, 1127.

[37] A. Leszczyńska, K. Stafin, J. Pagacz, M. Micusik, M. Omastova, E. Hebda, J. Pielichowski, D. Borschneck, J. Rose, K. Pielichowski, Ind. Crop. Prod., 2018, 116, 97.

[38] N. Hegyesi, Y. Zhang, A. Kohari, P. Polyak, X. Sui, B. Pukanszky, Ind. Crop. Prod., 2019, 141, 111799.

[39] Y. Zhang, L. Cui, H. Xu, X. Feng, B. Wang, B. Pukanszky, Z. Mao, X. Sui, Int. J. Biol. Macromol., 2019, 137, 197.

[40] O. Platnieks, S. Gaidukovs, A. Barkane, A. Sereda, G. Gaidukova, L. Grase, V.K. Thakur, I. Filipova, V. Fridrihsone, M. Skute, M. Laka, Polymers, 2020, 12, 1472.

[41] A. Pappu, V. Patil, S. Jain, A. Mahindrakar, R. Haque, V.K. Thakur, Int. J. Biol. Macromol., 2015, 79, 449.

[42] C. Zhang, R.Z. Zhang, Y.Q. Ma, W.B. Guan, X.L. Wu, X. Liu, H. Li, Y.L. Du, C.P. Pan, ACS Sustain. Chem. Eng., 2015, 3, 396.

[43] F. Lv, C. Wang, P. Zhu, C. Zhang, Cellulose, 2014, 21, 4405. 
[44] H. Huang, C. Liu, L. Zhang, G. Zhong, Z. Li, ACS Sustain. Chem. Eng., 2015, 3, 317.

[45] J. Puls, Macromol. Symposia, 1997, 120, 183.

[46] A. Ebringerova, Z. Hromadkova, T. Heinze, Adv. Polym. Sci., 2015, 186, 1.

[47] P. Gallezot, Chem. Soc. Rev., 2012, 18, 1538.

[48] V.K. Thakur, M.K. Thakur, M.R. Kessler, Handbook of Composites from Renewable Materials, Volume 6, Polymeric Composites, Wiley Scrivener Publishing, 2017.

[49] www.scopus.com (data dostępu 18.05.2021 r.).

[50] W. Boerjan, J. Ralph, M. Baucher, Annu. Rev. Plant Biol., 2003, 54, 519.

[51] R. Vanholme, B. Demedts, K. Morreel, J. Ralph, Plant Physiol., 2010, 153, 895.

[52] R.J.A. Gosselink, E. de Jong, B. Guran, A. Abächerli, Ind. Crop. Prod., 2004, 20, 121.

[53] G. Kickelbick, Hybrid Mater., 2014, 1, 39.

[54] V.K. Thakur, M.K. Thakur, P. Raghavan, M.R. Kessler, ACS Sustain. Chem. Eng., 2014, 2, 1072 .

[55] M. Goliszek, B. Podkościelna, O. Sevastyanova, K. Fila, A. Chabros, P. Pączkowski, Int. J. Biol. Macromol., 2019, 123, 910.

[56] M. Goliszek, B. Podkościelna, K. Fila, A.V. Riazanova, S. Aminzadeh, O. Sevastyanova, V.M. Gun'ko, Cellulose, 2018, 25, 5843.

[57] B. Podkościelna, M. Goliszek, O. Sevastyanova, Pure Appl. Chem., 2017, 89, 161.

[58] M. Sobiesiak, B. Podkościelna, O. Sevastyanowa, J. Anal. Appl. Pyrol., 2017, 123, 364.

[59] Ł. Klapiszewski, J. Zdarta, T. Jesionowski, Colloids Surf. B, 2018, 162, 90.

[60] J. Zdarta, Ł. Klapiszewski, A. Jędrzak, M. Nowicki, D. Moszyński, T. Jesionowski, Catalysts, $2017,7,1$.

[61] J. Zdarta, Ł. Klapiszewski, M. Wysokowski, M. Norman, A. Kołodziejczak-Radzimska, D. Moszyński, H. Ehrlich, H. Maciejewski, A.L. Stelling, T. Jesionowski, Mar. Drugs, 2015, 13, 2424.

[62] Ł. Klapiszewski, K. Siwińska-Stefańska, D. Kołodyńska, Chem. Eng. J., 2017, 330, 518.

[63] Ł. Klapiszewski, K. Siwińska-Stefańska, D. Kołodyńska, Chem. Eng. J., 2017, 314, 169.

[64] F. Ciesielczyk, P. Bartczak, Ł. Klapiszewski, T. Jesionowski, J. Hazard. Mater., 2017, 328, 150.

[65] Ł. Klapiszewski, P. Bartczak, M. Wysokowski, M. Jankowska, K. Kabat, T. Jesionowski, Chem. Eng. J., 2015, 260, 684.

[66] Ł. Klapiszewski, J. Zdarta, K. Antecka, K. Synoradzki, K. Siwińska-Stefańska, D. Moszyński, T. Jesionowski, Appl. Surf. Sci., 2017, 422, 94.

[67] K. Bula, Ł. Klapiszewski, A. Piasecki, T. Jesionowski, Materials, 2021, 14, 2114.

[68] Ł. Klapiszewski, B. Podkościelna, M. Goliszek, A. Kubiak, K. Młynarczyk, T. Jesionowski, Int. J. Biol. Macromol., 2021, 178, 344.

[69] K. Bula, G. Kubicki, T. Jesionowski, Ł. Klapiszewski, Materials, 2020, 13, 809.

[70] A. Grząbka-Zasadzińska, Ł. Klapiszewski, T. Jesionowski, S. Borysiak, Molecules, 2020, 25, 864.

[71] Ł. Klapiszewski, A. Grząbka-Zasadzińska, S. Borysiak, T. Jesionowski, Polym. Testing, 2019, 79, 106058.

[72] K. Bula, Ł. Klapiszewski, T. Jesionowski, Polym. Testing, 2019, 77, 105911.

[73] Ł. Klapiszewski, K. Bula, A. Dobrowolska, K. Czaczyk, T. Jesionowski, Polym. Testing, 2019, 73, 51 .

[74] Ł. Klapiszewski, F. Pawlak, J. Tomaszewska, T. Jesionowski, Polymers, 2015, 7, 1767.

[75] K. Bula, Ł. Klapiszewski, T. Jesionowski, Polym. Compos., 2015, 36, 913.

[76] A. Jamrozik, B. Strzemiecka, P. Jakubowska, I. Koltsov, Ł. Klapiszewski, A. Voelkel, T. Jesionowski, Int. J. Biol. Macromol., 2020, 161, 531.

[77] Ł. Klapiszewski, A. Jamrozik, B. Strzemiecka, P. Jakubowska, T.J. Szalaty, M. Szewczyńska, A. Voelkel, T. Jesionowski, Int. J. Biol. Macromol., 2019, 122, 88. 
[78] Ł. Klapiszewski, A. Jamrozik, B. Strzemiecka, I. Koltsov, B. Borek, D. Matykiewicz, A. Voelkel, T. Jesionowski, Molecules, 2017, 22, 1920.

[79] Ł. Klapiszewski, A. Jamrozik, B. Strzemiecka, D. Matykiewicz, A. Voelkel, T. Jesionowski, Int. J. Mol. Sci., 2017, 18, 1224.

[80] A. Ślosarczyk, I. Klapiszewska, P. Jędrzejczak, Ł. Klapiszewski, T. Jesionowski, Polymers, 2020, 12, 1180 .

[81] A. Ślosarczyk, Ł. Klapiszewski, T. Buchwald, P. Krawczyk, Ł. Kolanowski, G. Lota, Materials, 2020, 13, 400.

[82] Ł. Klapiszewski, I. Klapiszewska, A. Ślosarczyk, T. Jesionowski, Molecules, 2019, 24, 3544.

[83] T.J. Szalaty, Ł. Klapiszewski, T. Jesionowski, J. Mol. Liq., 2020, 301, 112417.

[84] Ł. Klapiszewski, T.J. Szalaty, A. Kubiak, A. Skrzypczak, A. Dobrowolska, K. Czaczyk, T. Jesionowski, J. Mol. Liq., 2019, 274, 370.

[85] T.J. Szalaty, Ł. Klapiszewski, M. Stanisz, D. Moszyński, A. Skrzypczak, T. Jesionowski, Int. J. Biol. Macromol., 2018, 119, 431.

[86] Ł. Klapiszewski, T.J. Szalaty, B. Kurc, M. Stanisz, B. Zawadzki, A. Skrzypczak, T. Jesionowski, ChemPlusChem, 2018, 83, 361.

[87] A. Jędrzak, T. Rębiś, Ł. Klapiszewski, J. Zdarta, G. Milczarek, T. Jesionowski, Sens. Actuator B: Chem., 2018, 256, 176.

[88] T. Jesionowski, Ł. Klapiszewski, G. Milczarek, J. Mater Sci., 2014, 49, 1376.

[89] T. Jesionowski, Ł. Klapiszewski, G. Milczarek, Mater. Chem. Phys., 2014, 147, 1049.

[90] M. Stanisz, Ł. Klapiszewski, T. Jesionowski, Chem. Eng. J., 2020, 397, 125409.

[91] M. Stanisz, Ł. Klapiszewski, D.T. Młynarczyk, B. Stanisz, T. Jesionowski, Molecules, 2020, 25, 3150 .

Praca wpłynęła do Redakcji 24 maja 2021 r. 
